\title{
Urgences
}

\section{il y a ceux...}

\section{Danielle Hawey}

Numéro 13, mars 1986

\section{Éclats d'atelier}

URI : https://id.erudit.org/iderudit/025235ar

DOI : https://doi.org/10.7202/025235ar

Aller au sommaire du numéro

\section{Éditeur(s)}

Urgences

\section{ISSN}

0226-9554 (imprimé)

1927-3924 (numérique)

Découvrir la revue

\section{Citer ce document}

Hawey, D. (1986). il y a ceux... Urgences, (13), 78-78.

https://doi.org/10.7202/025235ar

Ce document est protégé par la loi sur le droit d'auteur. L'utilisation des services d'Érudit (y compris la reproduction) est assujettie à sa politique d'utilisation que vous pouvez consulter en ligne.

https://apropos.erudit.org/fr/usagers/politique-dutilisation/ 


\section{Danielle Hawey}

il y a ceux pour qui, un mauvais songe à vrai dire, le reste du monde en somme, les vous, les tu, collés sur terre, les sans prélude, les sans décor, les sans désir, tu peux attendre, au suivant, le reste du monde, chacun sur son cratère, il y a ceux, enfoncés sous terre, sans étoile, sans château, sans musique, sans guerre ni paix, à l'acuité du regard, le reconnaître, au premier instant, sinon rien, au premier instant, tout ou rien, je serai prise, un prétexte pour le centre de la spyrosphère, flamme sortie des cendres du hasard, ironie du sort, yeux phares dans la nuit, yeux laser à lacérer le brouillard des cratères fumants, la musique enfile mon corps, dompté, sauvage, à sa guise à lui, dompté, sauvage, m'aiguise à lui, il ressemble à, il ressemble à, il ressemble à celui, qui tue, le reste, du monde, sans même forcer, empoigne ma crinière, je fléchis le cou, à genoux je pourrais, tué le reste du monde, à des années-lumière, je le devine guerrier, je suis la quatrième, les trois autres m'apprêtent, me baignent, me frottent d'huile parfumée, je subis leurs mains sur mon corps, elles veulent me cerner, me démystifier, se garder un semblant de survie, le guerrier, je l'attends et le crains, accroupie sur mes pieds d'enfant, me souffle des tempêtes à l'oreille, ébranle en rafales les recoins de mon corps, inonde la terre vulvaire, sa terre étrangère, son inaccessible, son convoité, glisse un doigt dans I'antre au fluide chaud, il, m'en parfume les tempes, les seins, il, dessine des arabesques de fluide sur le bas de mes reins, corps imprégné de l'odeur de l'écume, corps dompté, corps marqué, il, avance, le guerrier, se mélange à l'effluve, j'abandonne mon épaule frêle, nuque inclinée, mains liées, terre conquise, s'entrouvre en un cri, plus rien n'existe, mont de Vénus en volcan, tué le reste du monde, à des annéeslumière, nerfs fendus, flamme au thorax, roule, tambourine, danse démente, raz de marée, dérive d'une vague rive, où s'engloutir, se noyer, ressurgir, au reste du monde, les vous, les tu, sans décor, sans château, sans musique, toute la différence, un instant, des annéeslumière, je garde mon sexe, mais j'y laisse ma peau 